\title{
THE
}

\section{Age model and core-seismic integration for the Cenozoic Arctic Coring Expedition sediments from the Lomonosov Ridge}

\author{
Jan Backman \\ University of Rhode Island \\ Martin Jakobsson \\ University of Rhode Island \\ Martin Frank \\ Francesca Sangiorgi \\ Henk Brinkhuis
}

See next page for additional authors

Follow this and additional works at: https://digitalcommons.uri.edu/gsofacpubs

Terms of Use

All rights reserved under copyright.

\section{Citation/Publisher Attribution}

Backman, J., et al. (2008), Age model and core-seismic integration for the Cenozoic Arctic Coring Expedition sediments from the Lomonosov Ridge, Paleoceanography, 23, PA1S03, doi: 10.1029/ 2007PA001476.

Available at: https://doi.org/10.1029/2007PA001476

This Article is brought to you for free and open access by the Graduate School of Oceanography at DigitalCommons@URI. It has been accepted for inclusion in Graduate School of Oceanography Faculty Publications by an authorized administrator of DigitalCommons@URI. For more information, please contact digitalcommons-group@uri.edu. 


\section{Authors}

Jan Backman, Martin Jakobsson, Martin Frank, Francesca Sangiorgi, Henk Brinkhuis, Catherine Stickley, Matthew O'Regan, Reidar Løvlie, Heiko Pälike, David Spofforth, Jérôme Gattacecca, Kate Moran, John W. King, and Chip Heil 


\title{
Age model and core-seismic integration for the Cenozoic Arctic Coring Expedition sediments from the Lomonosov Ridge
}

\author{
Jan Backman, ${ }^{1}$ Martin Jakobsson, ${ }^{1}$ Martin Frank, ${ }^{2}$ Francesca Sangiorgi, ${ }^{3}$ Henk Brinkhuis, ${ }^{3}$ \\ Catherine Stickley, ${ }^{4}$ Matthew O'Regan, ${ }^{5}$ Reidar Løvlie, ${ }^{6}$ Heiko Pälike, ${ }^{7}$ David Spofforth, ${ }^{7}$ \\ Jérôme Gattacecca, ${ }^{8}$ Kate Moran, ${ }^{5}$ John King, ${ }^{5}$ and Chip Heil ${ }^{5}$
}

Received 29 April 2007; revised 7 August 2007; accepted 28 September 2007; published 13 March 2008.

[1] Cenozoic biostratigraphic, cosmogenic isotope, magnetostratigraphic, and cyclostratigraphic data derived from Integrated Ocean Drilling Program Expedition 302, the Arctic Coring Expedition (ACEX), are merged into a coherent age model. This age model has low resolution because of poor core recovery, limited availability of biostratigraphic information, and the complex nature of the magnetostratigraphic record. One $2.2 \mathrm{Ma}$ long hiatus occurs in the late Miocene; another spans $26 \mathrm{Ma}(18.2-44.4 \mathrm{Ma})$. The average sedimentation rate in the recovered Cenozoic sediments is about $15 \mathrm{~m} / \mathrm{Ma}$. Core-seismic correlation links the ACEX sediments to the reflection seismic stratigraphy of line AWI-91090, on which the ACEX sites were drilled. This seismostratigraphy can be correlated over wide geographic areas in the central Arctic Ocean, implying that the ACEX age model can be extended well beyond the drill sites.

Citation: Backman, J., et al. (2008), Age model and core-seismic integration for the Cenozoic Arctic Coring Expedition sediments from the Lomonosov Ridge, Paleoceanography, 23, PA1S03, doi:10.1029/2007PA001476.

\section{Introduction}

[2] The Cenozoic paleoceanography of the central Arctic Ocean was essentially unknown prior to ACEX drilling because of the extremely limited availability of prePleistocene sediments. Previous sampling from drifting ice islands and a few $(<10)$ icebreaker expeditions had recovered several hundred short sediment cores, but only three of these contained a few meters of sediments of Late Cretaceous age, and a single core had about a $1.8 \mathrm{~m}$ thick interval of biosilica bearing sediments of middle Eocene age [Clark, 1974; Bukry, 1984]. All other short cores were considered to be of "Late Cenozoic" [Thiede et al., 1990] or Pleistocene age [Backman et al., 2004]. Thus prior to ACEX, well over $90 \%$ of Cenozoic time was missing in the stratigraphy derived from these short central Arctic Ocean cores (Figure 1).

\footnotetext{
${ }^{1}$ Department of Geology and Geochemistry, Stockholm University, Stockholm, Sweden.

${ }^{2}$ Leibniz Institute for Marine Sciences at University of Kiel (IFMGEOMAR), Kiel, Germany.

${ }^{3}$ Laboratory of Palaeobotany and Palynology, Utrecht University, Utrecht, Netherlands.

${ }^{4}$ Norwegian Polar Institute, Tromsø, Norway.

${ }^{5}$ Graduate School of Oceanography and Department of Ocean Engineering, University of Rhode Island, Narragansett, Rhode Island, USA.

${ }^{6}$ Department of Earth Science, University of Bergen, Bergen, Norway.

${ }^{7}$ School of Ocean and Earth Science, National Oceanography Centre, University of Southampton, Southampton, UK.

${ }^{8}$ Department of Geophysics and Planetology, Centre Européen de Recherche et d'Enseignement de Géosciences de l'Environnement, CNRS, University of Aix-Marseille, Aix-en-Provence, France.
}

Copyright 2008 by the American Geophysical Union. 0883-8305/08/2007PA001476
[3] The ACEX drilling target was the approximately $450 \mathrm{~m}$ thick Cenozoic sedimentary drape on the crest of the Lomonosov Ridge near $88^{\circ} \mathrm{N}$ (Figure 2). Seismic reflection data from two key profiles crossing the Lomonosov Ridge had shown that these Cenozoic sediments rest on an angular unconformity of older sedimentary bedrock [Jokat et al., 1992]. The ACEX drill sites were chosen, based on ice conditions, from one of these two seismic profiles (AWI-91090), which were interpreted to represent continuous sediment deposition from the Holocene to the base of the middle Eocene [Jokat et al., 1995]. ACEX penetrated $428 \mathrm{~m}$ into this sediment sequence that drapes the crest of the Lomonosov Ridge near $88^{\circ} \mathrm{N}$ [Backman et al., 2006].

[4] Shipboard biostratigraphic analysis brought two major surprises, plus a fundamental clarification about sedimentation rates in the central Arctic Ocean. First, a mid-Cenozoic hiatus encompassing over $26 \mathrm{Ma}$ was unexpectedly encountered. Second, a record of latest Paleocene through early Eocene shallow marine sediments was unexpectedly recovered, including parts of the Paleocene Eocene Thermal Maximum interval. These and other key findings were subsequently reported by Moran et al. [2006], Brinkhuis et al. [2006], Sluijs et al. [2006], Pagani et al. [2006], and Stein et al. [2006]. Furthermore, one school of thought prior to ACEX had advocated that sedimentation rates in the central Arctic Ocean were on the $\mathrm{mm} / \mathrm{ka}$ scale [e.g., Steuerwald et al., 1968; Clark, 1970; Herman, 1974; Clark et al., 1980, 2000; Aksu and Mudie, 1985; Spielhagen et al., 1997; Jokat et al., 1999]. In contrast, sedimentation rates were reviewed by Backman et al. [2004], who argued that the central Arctic Ocean was not, on average, been a sediment starved basin during either Plio-Pleistocene or pre-Pliocene times, and that centimeter/kiloannum-scale 


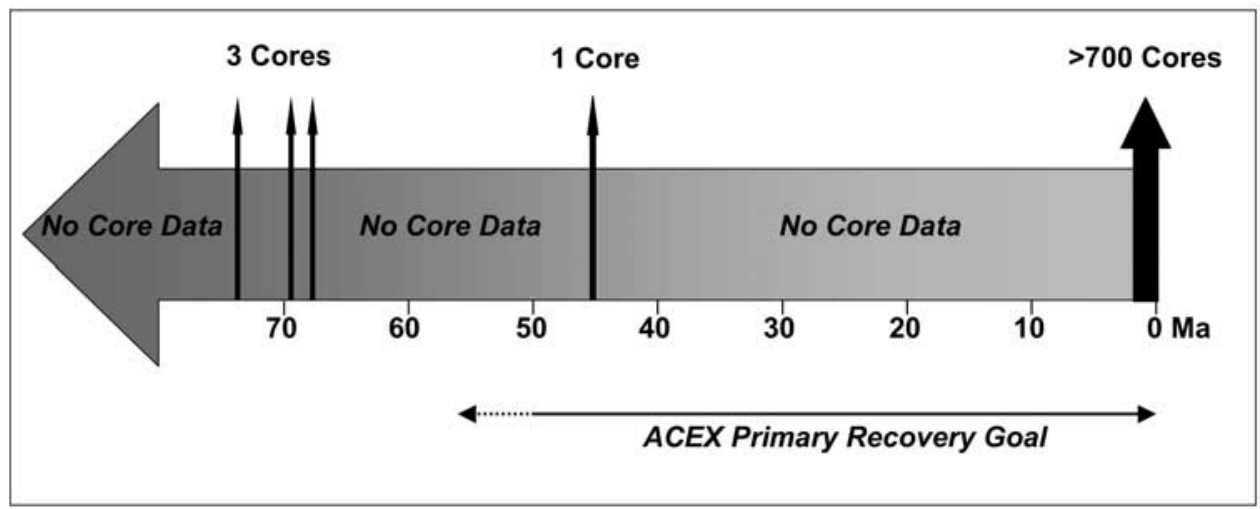

Figure 1. Stratigraphic coverage of existing cores in the central Arctic Ocean prior to ACEX and the recovery target for the ACEX drilling expedition. Well over $99 \%$ of all existing short cores were of Quaternary age prior to ACEX. The $1.8 \mathrm{~m}$ of middle Eocene sediments recovered, arbitrarily placed at $45 \mathrm{Ma}$, in a single core have a duration of $<100 \mathrm{ka}$. The three Late Cretaceous cores are arbitrarily placed on the time axis. Each of these has a duration, at the most, of a few hundred kiloyears.

sedimentation rates are the rule rather than the exception throughout the entire Arctic deep-sea basin. The ACEX shipboard biostratigraphers demonstrated that sediments of late Miocene age occurred at about $100 \mathrm{mbsf}$, confirming an average Pleistocene through late Miocene sedimentation rate clearly in excess of $10 \mathrm{~m} / \mathrm{Ma}(1 \mathrm{~cm} / \mathrm{ka})$ [Backman et al., 2006].

[5] Although the ACEX sediment age datums resolved the sedimentation rate discord, building a highly resolved and robust age model for the ACEX cores is challenging. Key elements that blur the time series in the ACEX cores include poor core recovery, in which about $1 / 3$ of the penetrated section was not recovered, the occurrence of an unexpected major hiatus, the limited availability of biostratigraphic indicators, and the enigmatic preservation of the geomagnetic polarity record.

[6] The key purposes of this paper are to amalgamate biostratigraphic, cosmogenic isotope, cyclostratigraphic and paleomagnetic data sets into a coherent age model for the Cenozoic sedimentary sequence recovered by ACEX, and to provide a short discussion of the problematic geomagnetic inclination pattern that explains our use of only one reversal boundary. In addition, a core-seismic integration model is presented.

\section{Choice of Timescale}

[7] Global Cenozoic timescales are still under development. Orbitally tuned cyclostratigraphic data are the chronological backbone in the most recent Neogene timescale, which includes "Quaternary" times [Lourens et al., 2004]. Their synthesis is considered to fairly well reflect the true progress of Neogene time. The Paleogene timescale, on the other hand, is less sharp and definitive, owing to the lack of a continuous Milankovitch-based Paleogene cyclostratigraphy, and it will therefore continue to develop and change over some years to come. The ACEX age model is therefore based on a combination of the following three timescales.

\subsection{Interval $0.000-23.030 \mathrm{Ma}$}

[8] The Neogene timescale of Lourens et al. [2004] is used. They placed the Paleogene/Neogene boundary at 23.030 Ma, based on an astronomically derived age for the base of Chron C6Cn.2n [Shackleton et al., 2000], updated to the new astronomical solution of Laskar et al. [2004] by Pälike et al. [2006b]. Pälike et al. [2006a] estimated an age of 23.026 Ma for this reversal boundary, that is, 4 ka younger than the Lourens et al. estimate.

\subsection{Interval 23.278-41.510 Ma}

[9] The Pälike et al. [2006a, Table S1] timescale is used from top C6Cn.3n at 23.278 Ma to the base of $\mathrm{C} 19 \mathrm{n}$ at $41.510 \mathrm{Ma}$. This implies that the $248 \mathrm{ka}$ long Chron C6Cn.2r is artificially shortened by $4 \mathrm{ka}(1.6 \%)$, when shifting from the Miocene to the Oligocene timescale.

\subsection{Interval 42.536-83.000 Ma}

[10] The Cande and Kent [1995] timescale is used from the top of Chron 20n to the top of Chron C34n. This implies that the 1.026 million year long Chron $\mathrm{C} 19 \mathrm{r}$ is artificially lengthened by $11 \mathrm{ka}(1.1 \%)$, when shifting from the Pälike et al. [2006] timescale to Cande and Kent's timescale. The impact of these two artificial timescale jumps (4 and $11 \mathrm{ka}$, respectively) on the data and discussions presented here is negligible.

\section{Problematic Paleomagnetic Record in the Central Arctic Ocean}

[11] The middle Miocene through Pleistocene paleomagnetic record shows a large number of short intervals with steep to intermediate positive and negative inclinations (Figure 3) [see also Backman et al., 2006, Figure F46]. This large number of polarity intervals is not compatible with the number of existing geomagnetic polarity zones/ subzones in established geomagnetic polarity timescales [Cande and Kent, 1995; Lourens et al., 2004], implying that the Neogene inclination pattern in the ACEX cores is 


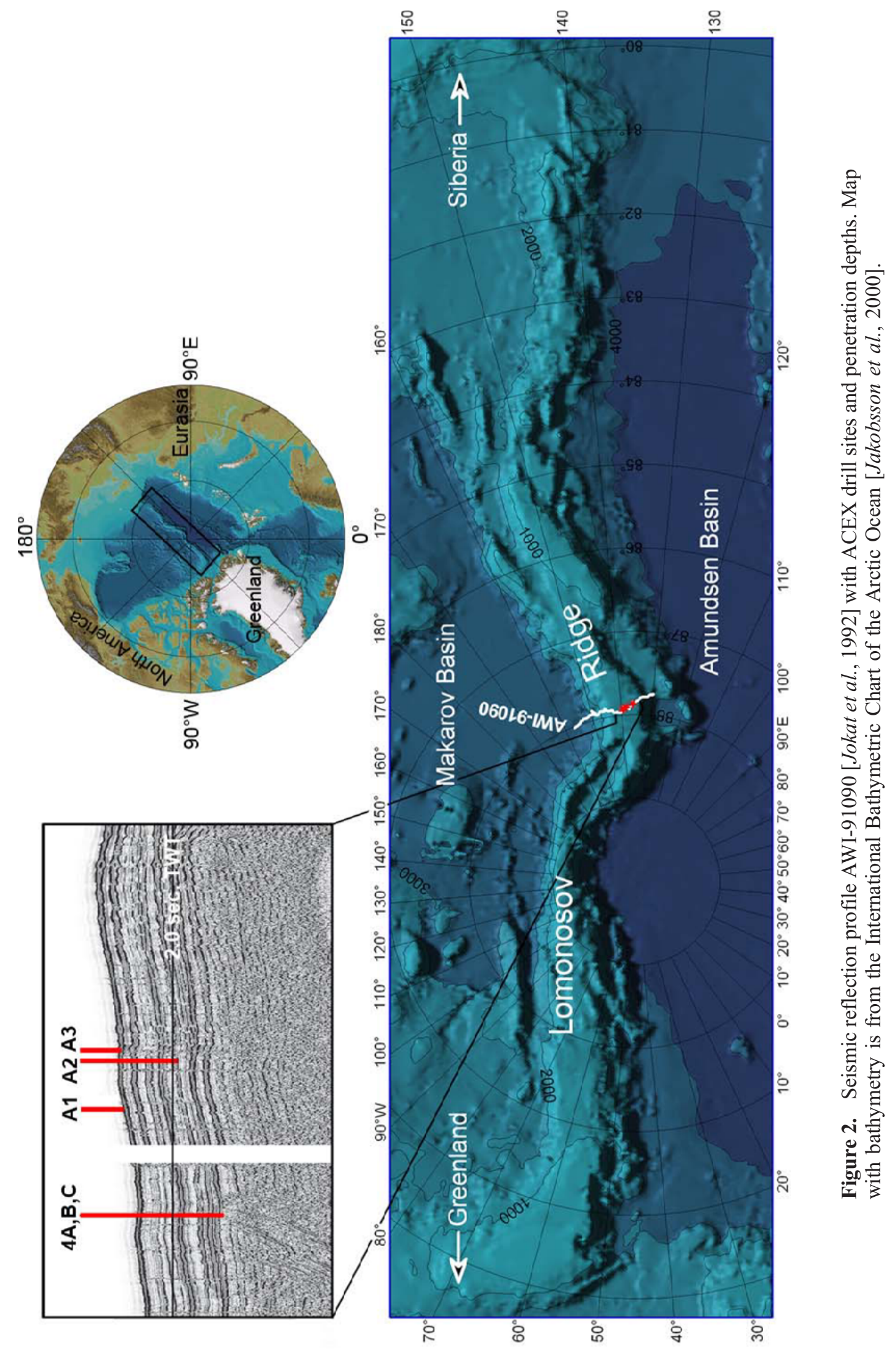



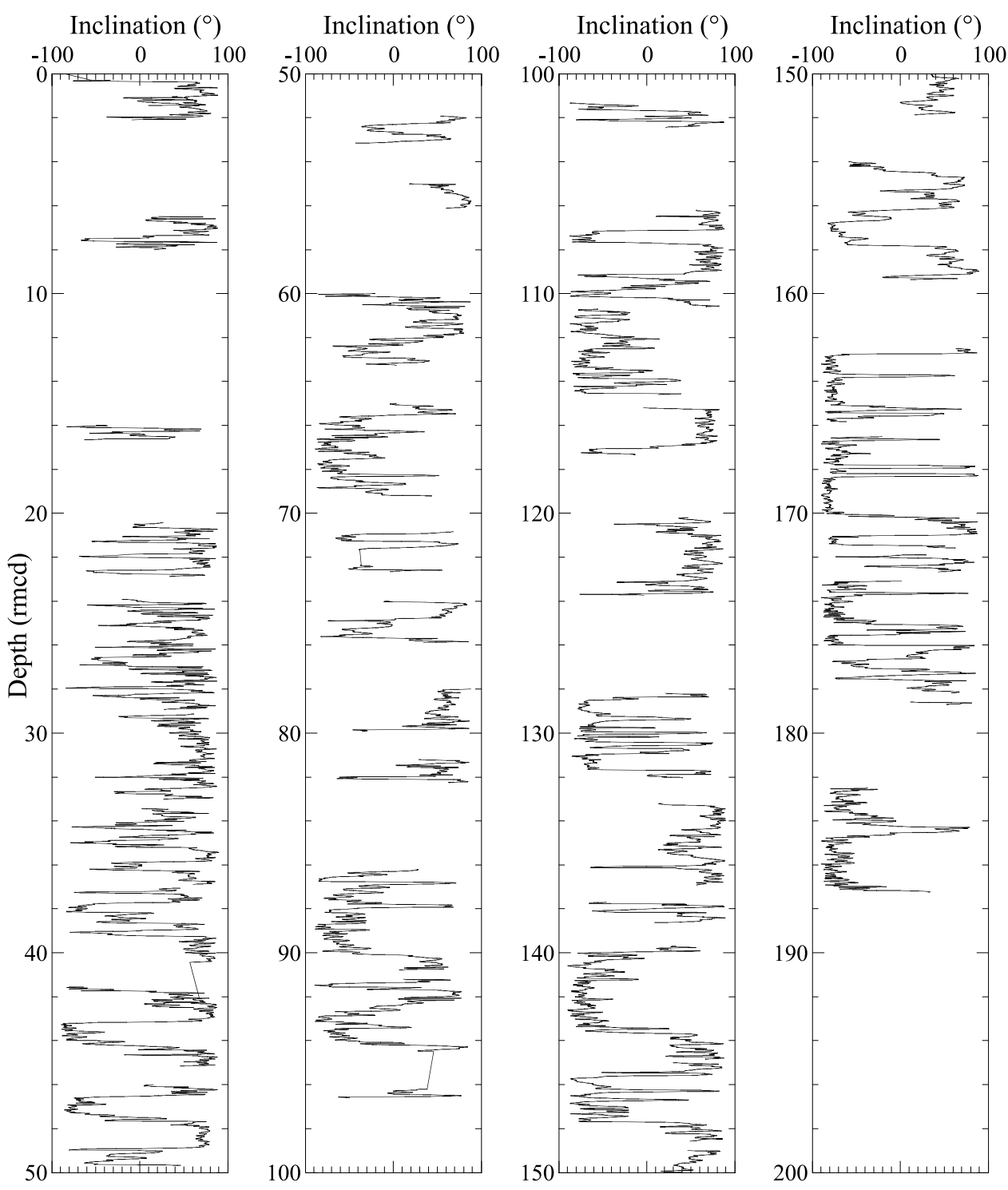

Figure 3. Variations with depth of natural remanent magnetization inclination at Hole M0002A after alternating field demagnetization at $40 \mathrm{mT}$. Abbreviation rmcd is revised meter-corrected depth. This depth scale is from O'Regan et al. [2008a].

difficult to interpret in terms of geomagnetic reversal boundaries. The discontinuous recovery of the ACEX sedimentary record and the lack of a rigorous independent age control adds to these difficulties. We have thus chosen to ignore the Neogene magnetostratigraphic data in developing the ACEX age model.

[12] Similar high-frequency variations in inclination have been reported from several piston cores from the central Arctic Ocean as well from the Greenland Sea [e.g., Løvlie et al., 1986; Bleil, 1987; Nowaczyk et al., 1994, 2001, 2003]. As Pleistocene sedimentation rates in the investigated cores are on the order of centimeters/kiloannum, this suggests that short-duration intervals with negative inclinations may represent geomagnetic excursions within the Brunhes Chron. A first problem, however, is that most short cores retrieved from low and middle latitudes, showing similar or higher sedimentation rates, rarely preserve geomagnetic excursions because of their limited duration. It follows that the inclination pattern recorded in the ACEX cores is by and large an Arctic phenomenon. A second problem is that polarity intervals in Arctic Ocean piston cores, as well as in the ACEX cores, are often several tens of centimeters thick. As excursions are considered to have durations of $<10 \mathrm{ka}$ [Gubbins, 1999], the lengths of the negative polarity intervals within what is perceived to represent the normal Brunhes Chron, or normal inclination intervals during the reversed Matuyama Chron, greatly exceed the thickness of typical excursions expected in sediments being deposited at rates of $10-20 \mathrm{~m} / \mathrm{Ma}$, the typical Neogene ACEX rate. This high-frequency geomagnetic pattern is particularly pronounced within the upper $23 \mathrm{~m}$ composite depth (mcd) of the ACEX cores [Backman et al., 2006, Figure F46]. High- 
frequency inclination changes of shorter length are, however, pervasive in the upper $185 \mathrm{mcd}$.

[13] The occurrence of these high-frequency polarity changes in the Neogene ACEX sediment sequence may represent either distortions of the paleomagnetic record, or the genuine behavior of the geomagnetic field in this part of the Arctic Ocean.

[14] Sediments deposited in the Arctic Ocean during a polarity chron acquire a magnetization in a subvertical field of maximum geomagnetic field intensity. During reversals or excursions, the main dipole field is weakened by $80-$ $90 \%$, and is largely dominated by higher-order harmonics of the geomagnetic field (quadrapole and octopole). This implies that Arctic Ocean sediments will be exposed to larger absolute variations in field strengths during excursions than sediments in lower-latitude oceans. On return to a dipole configuration, the increased field intensity may wipe out records of transitional, nondipole records. Consequently, any remagnetization due to a field-dependent increase in lock-in depth will be greater at higher latitudes [Coe and Liddicoat, 1994]. Preservation of the large number of inferred geomagnetic excursions in central Arctic Ocean sediments thus indicates shallow or negligible lock-in depths which, however, do not explain the high frequency character of the observed inclination records in Arctic piston cores or in the ACEX sediments.

[15] The lithological descriptions of the ACEX sediments indicate that the majority of the observed inclination changes occur in pristine intervals not affected by disturbances caused by the coring process. Moreover, there is no apparent systematic link between the lithological cycles and the observed pattern in the inclination record. Two remaining possible explanations are (1) the paleomagnetic record has been partially modified by chemical overprinting, that is to say, diagenetic processes, or alternatively, (2) the highfrequency inclination record in the ACEX cores represents genuine regional variability in the geomagnetic field. Further studies are needed in order to distinguish between these possibilities.

[16] The high-frequency, rather chaotic reversal patterns in the upper $192 \mathrm{mcd}$ and the weak intensity of natural remanent magnetization between about 192 and $388 \mathrm{mcd}$, in the range of $10^{-5}$ to $10^{-4} \mathrm{~A} / \mathrm{m}$, prevent recognition, in this entire interval, of Cenozoic geomagnetic reversal boundaries. The only unambiguously identified reversal boundary is the top of chron C25n at $399.63 \mathrm{mcd}$, corroborated by biostratigraphy, which shows a distinct reversal with stable inclination values in upper C25n and lower C24r [Backman et al., 2006, Figure F47].

\section{Age/Depth Control Points in the ACEX Sediments}

[17] The lack of an unambiguous paleomagnetic record that can be accurately interpreted in terms of properly identified polarity zones or reversal boundaries results in a strong dependence on the biostratigraphic and ${ }^{10} \mathrm{Be}$ data sets for our age control, the latter for the youngest approximately 12 million years. Biostratigraphic data in the ACEX sediments [Backman et al., 2006] are generally scarce, and considerably less well constrained when compared to data attainable in other Cenozoic deep-sea sequences. The poor biostratigraphic control can be attributed to a number of factors including the following: (1) Biogenic carbonate is discontinuous in the uppermost sediment column and not preserved at all below about $21 \mathrm{mcd}$. (2) Biogenic silica is not preserved in the Neogene sediments (upper $199 \mathrm{mcd}$ ) of the sediment column, or in the upper Paleocene and lower Eocene sediments (319-404 mcd). (3) Radiolarians occur only in a few middle Eocene samples, presumably excluded paleoecologically because of reduced surface water salinities. (4) Middle Eocene silicoflagellate, diatom and ebridian biohorizons are not precisely calibrated to magnetostratigraphy from the Arctic Ocean and therefore offer only general age assignments, e.g., "middle Eocene." (5) The presence of agglutinated benthic foraminifera at a few Neogene levels and in the lower Eocene offers, similarly, only imprecise stratigraphic information. (6) Neogene dinoflagellate taxa occur discontinuously and in low abundances. (7) The limited set of Neogene dinocyst events are calibrated in extra-Arctic areas, adding uncertainty to the reliability of these age estimate in the central Arctic Ocean; the situation is better in the Paleogene showing continuous and abundant dinoflagellates throughout, with several events calibrated in the neighboring Greenland Sea [Eldrett et al., 2004]. Despite these problems, the Cenozoic biostratigraphy is critical for establishing the history of sediment accumulation in the ACEX sediments, albeit at a low resolution and with less precision when compared to what can be generally accomplished using marine microfossils in tropical to subpolar oceans. The rare and discontinuous occurrences of Neogene dinoflagellate species, together with the lack of an unambiguous magnetostratigraphic record, make it difficult to assess whether or not the absolutely last or first observed specimens represent true evolutionary events. Rather than assuming that these occurrences represent the age calibrated first appearance or extinction of the species, it is assumed here that the sample containing the highest occurrence of a species represents an age that is equal to or older than its evolutionary extinction age, as derived from outside the central Arctic Ocean. Similarly, the sample containing the lowest occurrence of a species is assumed to represent an age that is equal to or younger than its evolutionary appearance age. This approach infers that the taxa did not appear earlier or disappear later within the central Arctic Ocean, relative to the regions in which the adopted appearance/extinction age estimates were obtained. In the Paleogene, this approach is applied to all silicoflagellate, diatom and most dinoflagellate events.

\subsection{Quaternary and Neogene Biostratigraphy}

[18] An isolated occurrence of common N. pachyderma (sinistral) were observed in a single sample at $19.3 \mathrm{mcd}$ (Figure 4), indicating a maximum age of about $1.8 \mathrm{Ma}$ for this sample according to Norwegian/Greenland Sea data [Spiegler, 1996]. Six dinoflagellate biohorizons, spanning the interval between about $14 \mathrm{Ma}$ and $1 \mathrm{Ma}$, are shown in the age model (Figure 4). Of these six events, two are bordered by barren intervals. Depth uncertainties of the last occurrence $(\mathrm{LO})$ of $H$. tectata $(1.0 \mathrm{Ma})$ and its first 
ACEX Age Model

Lith. Unit

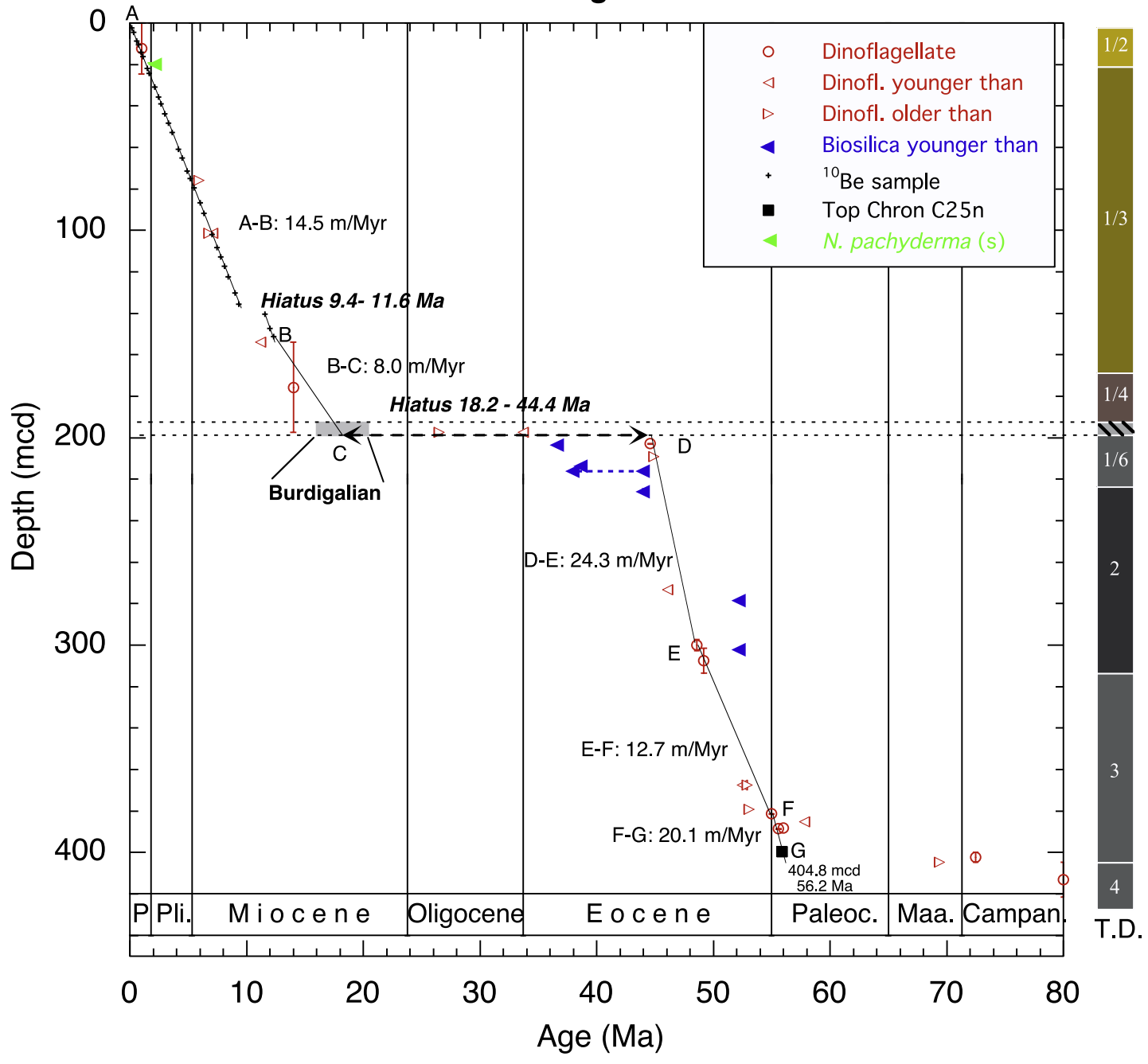

Figure 4. Age/depth plot with lithologic units and subunits (right column) [Backman et al., 2006]. TD is terminal depth. Depth is given in meters composite depth (mcd). Epochs are P, Pleistocene; Pli, Pliocene; Paleoc, Paleocene; Maa, Maastrichtian; and Campan, Campanian. Age/depth control points used to calculate sedimentation rates are listed in Table 1. Two age estimates are shown for the first occurrence of the silicoflagellate $C$. hexacantha at $216.05 \mathrm{mcd}$, connected by a dashed line. The older estimate $(44.1 \mathrm{Ma})$ is derived from the North Atlantic, whereas the younger $(37.9 \mathrm{Ma})$ is derived from Ocean Drilling Program Site 913B in the Greenland Sea [Stickley et al., 2008]. All age estimates refer to the timescale used here (see text). The age model around this hiatus is further discussed by Jakobsson et al. [2007].

occurrence (FO) (14.0 Ma) have thus been extended to include the nearest barren intervals. The remaining four dinoflagellate biohorizons only mark "younger than" or "older than" positions. A nearly monogeneric assemblage consisting of two periodiniod species, which resemble the cf. Batiacasphaera baculata sensu Manum et al. [1989] [see Sangiorgi et al., 2008a] occurs abundantly at $197.42 \mathrm{mcd}$, within lithological subunit $1 / 5$ (Table 1). This genus is not calibrated to magnetostratigraphy, but is indicative of an early Miocene, likely Burdigalian, age [Damassa, 1998; Williams and Manum, 1999]. With the lack of other indigenous age indicators in subunit $1 / 5$, its base at $198.70 \mathrm{mcd}$ is arbitrarily placed at the midpoint of the Burdigalian age range
(16.0-20.4 Ma), that is, at 18.2 Ma. The potential range of sedimentation rates and age uncertainties from 151.28 to $198.70 \mathrm{mcd}$ is discussed by Jakobsson et al. [2007].

\section{2. ${ }^{10}$ Be Stratigraphy}

[19] For the upper $151 \mathrm{mcd}$, within some scatter, an exponential down-core decrease of $239{ }^{10} \mathrm{Be}$ concentrations and ${ }^{10} \mathrm{Be} /{ }^{9} \mathrm{Be}$ with depth was identified [Frank et al., 2008]. It is assumed that ${ }^{10} \mathrm{Be}$ (half-life $=1.51$ million years) is produced at a constant rate, to the first order, through interaction of cosmic radiation with oxygen and nitrogen atoms in the upper atmosphere. Variations of field intensity are problematic, as described above which makes it difficult to directly correct the ${ }^{10} \mathrm{Be}$ data for production rate changes 
Table 1. Age/Depth Control Points, Sedimentation Rates, and Age Estimates of Lithostratigraphic Units

\begin{tabular}{|c|c|c|c|c|c|}
\hline & Event & $\begin{array}{c}\text { Meters } \\
\text { Composite Depth }\end{array}$ & $\begin{array}{l}\text { Age, } \\
\text { Ma }\end{array}$ & Interval & Meters/Ma \\
\hline & top of section & 0 & 0 & & \\
\hline & deepest ${ }^{10} \mathrm{Be}$ sample above middle-late Miocene hiatus & 135.49 & 9.36 & & 14.5 \\
\hline A & next deeper ${ }^{10} \mathrm{Be}$ sample, middle-late Miocene hiatus & 140.44 & 11.56 & & \\
\hline \multirow[t]{2}{*}{ B } & deepest ${ }^{\mathrm{i} 0} \mathrm{Be}$ sample & 151.28 & 12.31 & $\mathrm{~A}-\mathrm{B}$ & 14.5 \\
\hline & midpoint Burdigalian stage equals young end of Cenozoic hiatus & 198.70 & 18.2 & $\mathrm{~B}-\mathrm{C}$ & 8.0 \\
\hline $\mathrm{C}$ & extrapolate up from $\mathrm{D}$, to old end of Cenozoic hiatus & 198.70 & 44.4 & & \\
\hline $\mathrm{D}$ & last abundant occurrence of $P$. clithridium & 202.95 & 44.6 & $D-E$ & 24.3 \\
\hline E & last occurrence of Azolla spp. & 299.95 & 48.6 & $E-F$ & 12.7 \\
\hline $\mathrm{F}$ & last occurrence of $A$. augustum & 381.42 & 55.0 & $\mathrm{~F}-\mathrm{G}$ & 20.1 \\
\hline G & top chron $\mathrm{C} 25 \mathrm{n}$ & 399.63 & 55.904 & & \\
\hline \multicolumn{6}{|c|}{ Average sedimentation rates } \\
\hline Neogene $^{\mathrm{a}}$ & & & & & 12.4 \\
\hline Paleogene ${ }^{b}$ & & & & & 17.6 \\
\hline Total section $^{\mathrm{c}}$ & & & & & 14.6 \\
\hline Hole & Base of Unit/Subunit & & & & \\
\hline $2 \mathrm{~A}$ & subunit $1 / 1$ & 2.11 & 0.15 & & \\
\hline $2 \mathrm{~A}$ & subunit $1 / 2$ & 21.22 & 1.5 & & \\
\hline $2 \mathrm{~A}$ & subunit $1 / 3$ & 168.53 & 14.5 & & \\
\hline $2 \mathrm{~A}$ & subunit $1 / 4$ & 192.94 & 17.5 & & \\
\hline $2 \mathrm{~A}$ & subunit $1 / 5$ & 198.70 & 18.2 & & \\
\hline $2 \mathrm{~A}$ & subunit $1 / 6$ & 223.56 & 45.4 & & \\
\hline $4 \mathrm{~A}$ & unit 2 & 313.61 & 49.7 & & \\
\hline $4 \mathrm{~A}$ & unit 3 & 404.79 & 56.2 & & \\
\hline
\end{tabular}

${ }^{\mathrm{a}}$ Neogene: $198.7 \mathrm{~m} /(18.2-2.2) \mathrm{Ma}$; total time interval minus $2.2 \mathrm{Ma}$ long hiatus.

baleogene: $(404.8-198.7) \mathrm{m} /(56.2-44.4) \mathrm{Ma}$.

${ }^{\mathrm{c}}$ Total section $(404.8 \mathrm{~m})$ deposited over $27.8 \mathrm{Ma}(56.2-2.2-26.2)$.

[Frank et al., 2008]. Several approaches were followed to constrain the age depth relationship on the basis of the ${ }^{10} \mathrm{Be}$ data. The most reliable estimate of the average sedimentation rate is obtained by normalizing the ${ }^{10} \mathrm{Be}$ concentrations to authigenic, that is, seawater derived, stable ${ }^{9} \mathrm{Be}$ from the same samples, which eliminates sedimentary dilution effects. An exponential fit to all ${ }^{10} \mathrm{Be} /{ }^{9} \mathrm{Be}$ data in the upper 135.5 mcd results in an average sedimentation rate of $14.5 \mathrm{~m} / \mathrm{Ma}$ [Frank et al., 2008]. This results in an age of $9.4 \mathrm{Ma}$ at $135.49 \mathrm{mcd}$. Between $135.49 \mathrm{mcd}$ and $140.44 \mathrm{mcd}$, the ${ }^{10} \mathrm{Be} /{ }^{9} \mathrm{Be}$ data indicate the presence of a hiatus with a duration of about 2.2 million years. The sedimentation rate between $140.44-151.28$ mcd is identical to, within the estimated error, the rate in the overlying $0.0-$ $135.49 \mathrm{mcd}$ interval, resulting in an age of $12.3 \mathrm{Ma}$ for the deepest ${ }^{10} \mathrm{Be}$ sample at 151.28 mcd. Different fits and normalization procedures carried out on the data did not result in deviations larger than \pm 1 million years from this estimate [Frank et al., 2008]. The uncertainty of the half-life of ${ }^{10} \mathrm{Be}$ as well as production rate changes, caused variations in the geomagnetic field intensity are included in this error estimate.

\subsection{Paleogene Biostratigraphy}

[20] Sediments of late early Miocene age in subunit $1 / 5$ rest on sediments of middle Eocene age in subunit 1/6, marking a hiatus composed of about $40 \%$ of Cenozoic time, at $198.70 \mathrm{mcd}$ (Figure 4 and Table 1). Biosiliceous micro- fossils are not preserved above $202.10 \mathrm{mcd}$. Their abundance relationships, biostratigraphy and paleoecology are discussed by Backman et al. [2006, Figures F10-F12], Stickley et al. [2008], and K. Katsuki et al. (Earliest middle Eocene diatom paleoceanography in the central Arctic Ocean at IODP 302 Site M0004, submitted to Micropaleontology, 2007). Subunit $1 / 6$ shows a mixed biostratigraphic signal, in which the biosilica events (diatoms and silicoflagellates) suggest a younger age than the dinoflagellate events. In particular, the FO of the diatom Coscinodiscus aff. tenerrimus (203.12 mcd) suggests an earliest late Eocene age, based on our calibration of this previously reported event in Ocean Drilling Program Site 913B [Scherer and Koç, 1996] to the later published magnetostratigraphic record of the same site [Eldrett et al., 2004], rather than a middle Eocene age for the uppermost part of subunit 1/6. A study of dinoflagellate cysts in subunit $1 / 6$ shows the last abundant occurrence of Phthanoperidinium clithridium at $202.95 \mathrm{mcd}$. When taking into account that dinoflagellates are present throughout subunit $1 / 6$ and that this stratigraphic interval shows a complete lack of latest middle through late Eocene dinoflagellate taxa, it appears reasonable to assume that the last abundant occurrence of P. clithridium reflects the extinction at $44.6 \mathrm{Ma}$ of this species as determined from the Greenland Sea [Eldrett et al., 2004]. Another dinoflagellate event at $209.30 \mathrm{mcd}$, the LO of Cerodinium depressum (44.9 Ma), has a position that 
is consistent with a middle middle Eocene assignment for the upper part of subunit 1/6, rather than a late(st) middle Eocene age. At present, we do not know if the large age discrepancy of 7.9 million years between the $C$. aff. tenerrimus $(36.7 \mathrm{Ma})$ and $P$. clithridium (44.6 Ma) biohorizons is caused by calibration problems, a paleoecologically induced time transgression, or other factor(s). This problem appears resolvable only through future studies of diatom/ silicoflagellate and dinoflagellate bearing strata from northern high latitudes in which an independent time control can be established. Two other palynological bioevents are used to constrain the sedimentation rate in the early Eocene, namely the LOs of Azolla spp. and Apectodinium augustum [Backman et al., 2006; Brinkhuis et al., 2006; Sluijs et al., 2006]. In the late Paleocene, the top of Chron C25n is used, resulting in a sedimentation rate of $20 \mathrm{~m} / \mathrm{million}$ years, which is extrapolated to the oldest Paleocene sediments recovered a $404.8 \mathrm{mcd}$ (56.2 Ma). Below that level, ACEX penetrated another $22 \mathrm{~m}$, although only $1.4 \mathrm{~m}(6.3 \%)$ was recovered. Palynological data indicate a Campanian age, circa $80 \mathrm{Ma}$, for the oldest recovered sediments.

\section{Cyclostratigraphic Control of Sedimentation Rates in Lithostratigraphic Subunit 1/6 and Unit 2}

[21] Significant advances have recently been made in the quest to obtain highly accurate and resolved geological timescales for the Neogene [e.g., Lourens et al., 2004], fundamentally relying on the Earth's built-in metronome that takes the form of astronomically driven "Milankovitch" type variations in Earth's insolation that are recorded in the sedimentary archive after having passed through the Earth's climate filtering system. Unlike radioisotopic dating methods, the observation of astronomically driven sedimentary cycles offers, in principle, similar precision during the Paleogene as in the Neogene, with relative errors on the order of a single cycle, for example $\approx 22,41,120$ or $405 \mathrm{ka}$, and associated constraints [Laskar, 1999]. The determination and application of climatic cycles, responding to insolation forcing, typically requires continuous long and high-resolution records, with additional good age control through previously calibrated biostratigraphic or magnetostratigraphic data, so as to make it possible to decipher anchoring points in the repetitive pattern of Earth's insolation, and to determine which of the three contributors to insolation variations (climatic precession, obliquity, short and long eccentricity) are dominant in any given measured parameter. In the case of the ACEX record, these requirements are only partially met, as stratigraphic sections below the top few tens of meters are not fully recovered, and age control is mainly provided by biostratigraphic means. Thus the same factors that make it difficult to achieve high resolution and accurate age model in the ACEX cores also hinder the cyclostratigraphic analysis of these cores. Nevertheless, the physical property data measured from the ACEX cores [Backman et al., 2006], as well as additional highresolution data such as organic carbon contents [Stein et al., 2006] and X-ray fluorescence (XRF) core scanner derived relative elemental concentrations [Spofforth et al., 2008] show a striking cyclical pattern within specific intervals on decimeter to meter scales. In order to validate the age model presented thus and by applying certain assumptions about the relationship between dominant forcing cycles, it is possible to further constrain the relative rates of sediment deposition. The approach used here is different from the way that astronomically driven variations are usually exploited, in that we do not match the core data to astronomical templates, but instead analyze the frequency ratio of those cycles that are preserved and assume that the exact ratio of sedimentary cycle frequencies should follow the pattern predicted by astronomy (roughly $400 \mathrm{ka}: 120 \mathrm{ka}: 41 \mathrm{ka}: 22$ ka ratios), such that variable sedimentation rates are reflected in a predictable pattern of frequency ratios. In addition, one would like to achieve a sedimentation rate solution that fulfils additional constraints, such as geologically feasible changes in sedimentation rates, and the ability to reconcile different available proxy curves with the frequency approach to derive sedimentation rates. This approach is detailed by Pälike et al. [2008], and utilizes data from high-resolution XRF measurements [Spofforth et al., 2008], and in parts, high-resolution biological proxy curves [Sangiorgi et al., 2008 b]. We achieve this by (1) extracting cyclical variation that is common to multiple parameters (multichannel singular spectral analysis (MSSA) [Plaut and Vautard, 1994; Jiang et al., 1995]) and (2) performing a wavelet frequency analysis of the extracted summary curve to establish sedimentation rates that are compatible with the orbital assumption [Torrence and Compo, 1998]. Figure 5 shows an example of our approach. Figure 5a shows a set of highresolution XRF titanium measurements on ACEX cores from lithologic subunits 1.5, 1.6, and unit 2 [Spofforth et al., 2008]. Figure 5b shows a wavelet spectral decomposition of these data, after they are interpolated to a common depth resolution (about $1 \mathrm{~cm}$ ). Superimposed are the predicted position of cycle gridgesh that would result from the age model presented in this paper, using the frequency ratios of eccentricity, obliquity, and climatic precession. It is clear from this figure that the XRF data are able to pinpoint the position of major sedimentary breaks, for example, near 198.78 m. "Hot" red colors in Figure 5b indicate higheramplitude variations at a particular combination of cycle period and position down core. Figures $5 \mathrm{c}$ and $5 \mathrm{e}$ apply the frequency ratio test to two subsections from the available data, for the interval $\sim 203$ to $220 \mathrm{mcd}$ (part of subunit 1.6), as well as to a core from lithologic unit 2 (302-2A-55X) for which a multitude of additional biological proxy data exist [Sangiorgi et al., 2008b]. Our results from unit 2 indicate an almost perfect match with the sedimentation rates predicted from the combined age model presented thus yielding around $25 \mathrm{~m} / \mathrm{Ma}$ (Figure 5e), reflected through very clear and persistent approximately $50 \mathrm{~cm}$ and $1 \mathrm{~m}$ cycles that reflect climatic precession and obliquity variations, respectively. For subunit 1.6 (Figures 5c and 5d), the situation is more complex. Here XRF data fluctuate strongly, but consistently, with periods of about $8 \mathrm{~cm}$, superimposed on longer-term cycles. There are two possible interpretations of this cycle pattern, resulting in different sedimentation rates. Taking the high-frequency variations present consistently in parameters such as $\mathrm{Ti}, \mathrm{Si}, \mathrm{Al}$, and anticorrelated in XRF Fe concentrations as the shortest possible set of Milankovitch cycles 
Exp 302 Site 2A Ti (cps) Wavelet (Morlet) analysis

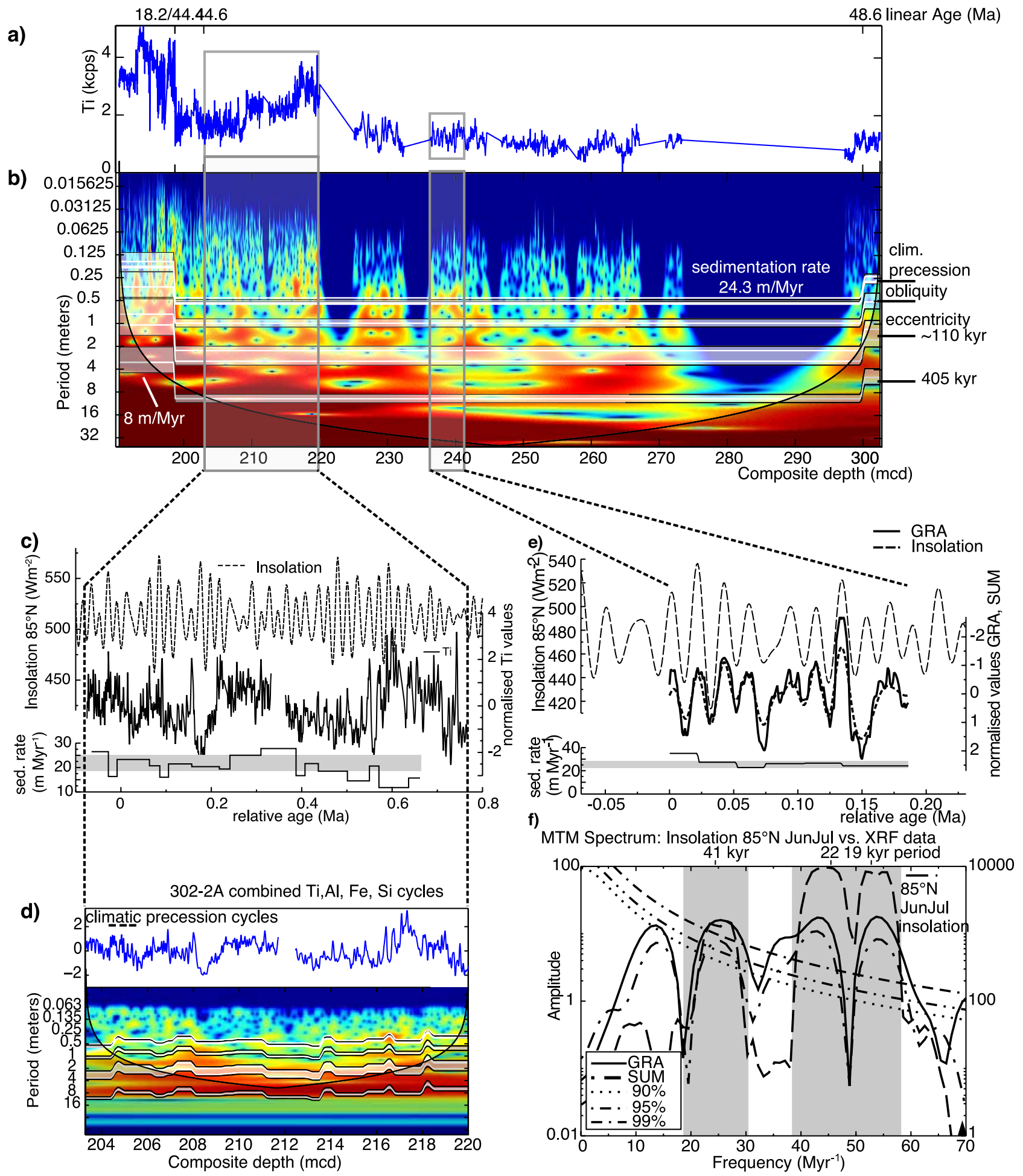

Figure 5 
(climatic precession, approximately $22 \mathrm{ka}$ duration), results in sedimentation rates between 6 to $8 \mathrm{~m} / \mathrm{Ma}$, significantly lower than in unit 2. However, this sedimentation rate determination is not unique and, alternatively, one can also invoke a model whereby climatic precession cycles correspond to longer approximately $40 \mathrm{~cm}$ cycles, with a superimposed higher oscillation that might not reflect Milankovitch-type cyclicity, for example biscuiting of core material or aliasing from variations below the sampling rate, to arrive at a sedimentation rate of again about $20 \mathrm{~m} / \mathrm{Ma}$. Both of these snapshots confirm the overall compatibility of cyclostratigraphic approaches with centimeter/kiloannum sedimentation rates in the Arctic Ocean during the Paleogene.

\section{A Regional Extension of the ACEX Paleoceanographic Record Through Core Seismic Integration}

[22] The ACEX sites are located along the seismic reflection profile AWI-91090 (Figure 2) [Jokat et al., 1992]. On the basis of these reflection data, a seismostratigraphic subdivision of the imaged Lomonosov Ridge sediment sequence was established by Jokat et al. [1995]. Their fourfold subdivision of the sediments draping the ridge crest, LR-3 to LR-6, with LR-6 at the top, corresponds to ACEX lithostratigraphic units 1 through 3 [Backman et al., 2006]. ACEX unit 1 contains both LR-5 and LR-6 (Figure 6). The base of LR-3 is equivalent to the base of ACEX unit 3, which marks a regional unconformity separating the sediment drape from the underlying sedimentary bedrock (Figure 6). Sediment physical property measurements on the ACEX cores included gamma ray attenuation bulk density and P wave velocity [Backman et al., 2006]. These data sets were used for synthetic seismic modeling with the purpose of integrating the ACEX sediment sequence with the seismic reflection profile AWI 91090. The synthetic seismic modeling was performed assuming planar waves, with no multiples or signal attenuation [Mayer et al., 1985], and using software by Divesto ${ }^{(\mathbb{M})}$. The calculated reflectivity coefficient time series derived from bulk density and velocity was sampled at $0.25 \mathrm{~ms}$ and convoluted with a Ricker wavelet having a peak frequency of $40 \mathrm{~Hz}$ and a period of $19.5 \mathrm{~ms}$. The characteristic of the wavelet was designed to simulate the seismic reflection profile AWI91090 (W. Jokat, personal communication, 2004), which was collected using two $3 \mathrm{~L}$, approximately 183 cubic inch, air guns and a $300 \mathrm{~m}$ long 12-channel streamer [Jokat et al., 1992]. Logged P wave velocities were not corrected to simulate in situ conditions with respect to water depth (pressure) and temperature. Nor were any corrections for porosity rebound applied. Depths (mcd) to the modeled reflectors were estimated by using $\mathrm{P}$ wave velocity data.

\subsection{Core Seismic Integration: Linking the ACEX Stratigraphy With Seismic Profile 408 AWI-91090}

[23] Brief summaries of the lithostratigraphic units described by the ACEX scientific party [Backman et al., 2006], the seismic reflectors that characterize each unit and/or subunit, and how these reflectors correlate to the synthetic seismogram generated from physical property data in the ACEX cores are provided in sections 6.2-6.4.

\subsection{Lithostratigraphic Unit $1(0.0-223.6 \mathrm{mcd})$}

[24] Lithologic subunit $1 / 1$ consists of silty clay and sandy mud. It is $<5 \mathrm{~m}$ thick and hence much thinner than the $\approx 9 \mathrm{~m}$ resolution of seismic profile AWI-91090. Below this subunit, the sediment density increases to values of about $1.9 \mathrm{~g} / \mathrm{cm}^{2}$ approximately $4 \mathrm{~m}$ above the base of subunit 1/2, which ends at $21.2 \mathrm{mcd}$ (Figure 6). There is a distinct reflector in the AWI seismic profile that roughly corresponds to the depth of the bottom of subunit $1 / 2$. In the synthetic seismic model, however, there is only a minor reversed reflector at the base of subunit $1 / 2$ (Figure 6). Subunit $1 / 3$ spans from $21.2 \mathrm{mcd}$ to $168.5 \mathrm{mcd}$. Several reflectors are generated in the uppermost $60 \mathrm{~m}$. The upper two of these reflectors occur where the core logging data contains numerous small gaps, making the exact depth positions of these reflectors uncertain. The lowermost two reflectors near $0.1 \mathrm{~s}$ TWT are closely spaced and appear to correlate to the base of reflector LR-6 [Jokat et al., 1995] (Figure 6). Their peaks are centered at $71 \mathrm{mcd}$ and $82 \mathrm{mcd}$, respectively. The sediment lithology does not manifest any large or sharp changes over this depth interval. The base of subunit $1 / 3$ at 168.5 mcd shows a velocity and density decrease, resulting in a modeled reversed amplitude reflector in the synthetic seismogram. The visual distinction

Figure 5. Summary of sedimentation rate determination with a cyclostratigraphic approach. (a) Ti counts (thousands of counts per second (kcps)) measured by X-ray fluorescence (XRF) core scanner on ACEX cores from units 1.6 and 2 [Spofforth et al., 2008]. Data are plotted versus meters composite depth (mcd) [Backman et al., 2006]. At the top of Figure $5 \mathrm{a}$, ages (in Ma) are indicated from the integrated age model presented here. (b) Wavelet analysis of data from Figure 5a (following Torrence and Compo [1998]), again plotted against mcd. Left-hand scale indicates cycle period in meters. Superimposed are four horizontal traces that indicate at which period the main Milankovitch periodicities would occur using the age model plotted in Figure 5a. Main implied sedimentation rate is $\sim 24.3 \mathrm{~m} / \mathrm{Ma}$ between about 300 and 198.8 mcd and $8 \mathrm{~m} / \mathrm{Ma}$ above $198.8 \mathrm{mcd}$. Vertical grey boxes marks specific study intervals (203.3-220 mcd and 236-241 mcd). Area below thick black line in bottom of Figure $5 \mathrm{~b}$ indicates gcone of influenceh where edge effects influence the spectrum. (c) One out of two options of fitting observed cycles to insolation at $85^{\circ} \mathrm{N}$ [Laskar et al., 2004], together with sedimentation rate. (d) Wavelet analysis of interval using combined signal extracted from Ti, Al, Si, and Fe XRF data by multichannel singular spectral analysis (MSSA) [Plaut and Vautard, 1994], together with predicted Milankovitch cycles from Figure 5c. (e) XRF-derived cycles from core 302-2A-55X [Sangiorgi et al., 2008b] and implied sedimentation rates. (f) Spectral analysis of insolation (dashed line), gamma ray absorption (GRA) bulk density, and summary (SUM) signal extracted by MSSA from bulk density, magnetic susceptibility, XRF Ti, Al, K, and natural gamma measurements, together with autoregressive noise models at 90\%, 95\%, and 99\% significance. 


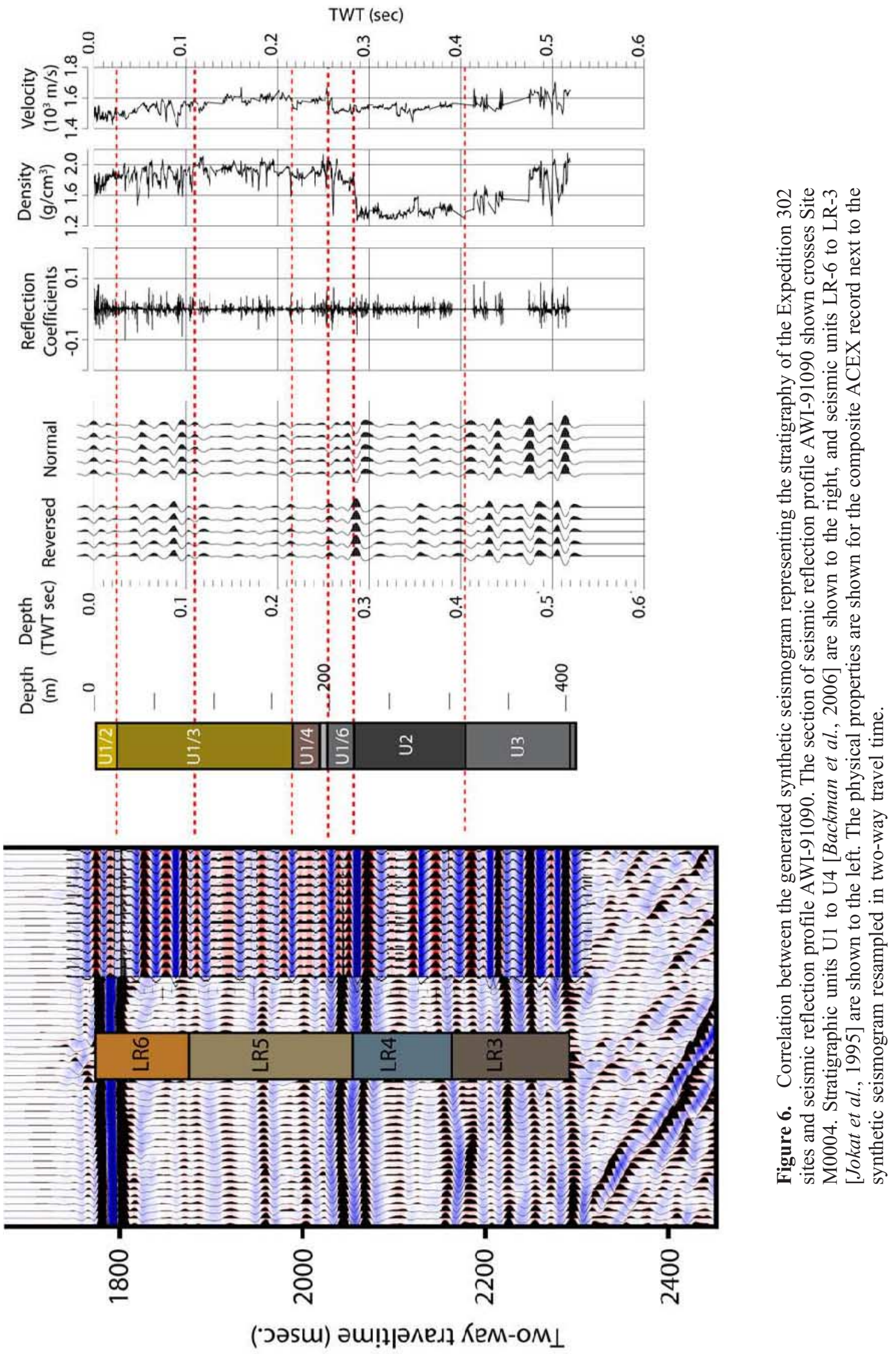


between subunits $1 / 3$ and $1 / 4$ is primarily based on a downcore change in sediment color from olive to brown. The synthetic seismogram shows a weak reflector at the transition between subunits $1 / 4$ and $1 / 5$, and a corresponding reflector is observed in AWI-91090 (Figure 6). The most significant velocity change in the ACEX sequence occurs at the base of subunit $1 / 5$ over the transition into the underlying subunit $1 /$ 6 , which caused a modeled velocity controlled reflector in the synthetic seismogram. This reflector marks a critical change in the paleoceanography of the Arctic Ocean, namely the initial transition from being a poorly ventilated landlocked sea into a well ventilated ocean. This change is attributed to the opening of the Fram Strait [Jakobsson et al., 2007]. The base of subunit $1 / 5$ coincides with a major Cenozoic hiatus. It is assumed that the occurrence of the seismic reflections at the subunit $1 / 5$ and $1 / 6$ boundary is strongly influenced by this hiatus.

\subsection{Lithostratigraphic Unit 2 (223.6-313.6 mcd)}

[25] The base of subunit $1 / 6$ at 223.6 mcd is distinguished by a large decrease in density. This change in physical properties represents a change in composition from siliciclastic sediments above to the mud bearing biosiliceous ooze below. Unit 2 is characterized by these biosilica-rich sediments [Backman et al., 2006]. A reversed reflector is modeled in the synthetic seismogram because of the velocity change at the unit 1 and unit 2 boundary (Figure 6), which correlates with the LR-5 and LR-4 boundary of Jokat et al. [1995]. In the seismic profile (AWI-91090), the interface between units LR-5 and LR-4 can be correlated to the seismic stratigraphy of the Amundsen Basin [Jokat et al., 1995]. Furthermore, three different seismic units (I, II, III) have been identified from Russian and previous Soviet seismic reflection and refraction data acquired from the Lomonosov Ridge, the Makarov and Amundsen Basins, and the East Siberian continental margin slope (see Figure 2 for place names) [Langinen et al., 2003]. The Langinen et al. seismic unit I correlates with, and encompasses, unit LR5 and LR-6. It follows that the base of ACEX unit 1 coincides with this seismic marker and that the transition to ACEX unit 2 can be traced via reflection seismics to both the Amerasian and Eurasian Basins.

\subsection{Lithostratigraphic Unit 3 (313.6-404.8 $\mathrm{mcd})$}

[26] The core recovery is less than 50\% in Hole M0004A, corresponding to lower unit 2 through unit 4 [Backman et al., 2006]. The lithology changes from mud-bearing biosiliceous ooze in unit 2 to siliciclastic sediments, mainly composed of clay and silty clay, in unit 3. Despite the poor recovery, it is evident that the sediment sequence of unit 3 contains large contrasts in physical properties that generate prominent reflectors (Figure 6). The recovery gaps blur the exact stratigraphic positions of the modeled reflectors. Still, the correlation between the synthetic seismogram and seismic profile (AWI-91090) shows a remarkably good fit too good to be coincidental (Figure 6). We suggest that the LR-4 correlates with ACEX unit 2, and LR-3 with unit 3.

\section{Conclusions}

[27] Geological age models are dynamic and ongoing refinements, to varying degrees, are the norm. This is particularly true for the ACEX sedimentary sequence, which was not only recovered from a very challenging physical environment, but also resulted in a challenging age model situation because of the low core recovery and paucity of age markers. The ACEX age model presented here represents a revised effort to establish a Cenozoic age model from a deep-sea sediment sequence in the central Arctic Ocean. The first effort was presented by Backman et al. [2006], and the second was a partly modified version [Moran et al., 2006]. This third effort differs from previous versions chiefly through the exclusion of all Neogene magnetostratigraphic data, the addition of more precisely determined, in terms of depth control, biostratigraphic indicators, the use of a revised depth scale in the uppermost $55 \mathrm{~m}$ of the sediment sequence [O'Regan et al., 2008b], and the use of cyclostratigraphy for constraining sedimentation rates. Finally, the regression line $\left(\mathrm{r}^{2}=0.94\right)$ of the ${ }^{10} \mathrm{Be}$ scatter in the upper $151 \mathrm{mcd}$ is calculated using this revised depth scale. Plio-Pleistocene sedimentation rates are on the order of $14-15 \mathrm{~m} / \mathrm{Ma}(1.4-1.5 \mathrm{~cm} / 1000$ years). This rate is 10-30 times higher when compared with the long held dominant view that sedimentation rates were quite low and the central Arctic Ocean was a sediment-starved basin [Clark et al., 1980]. With only two age events constraining Neogene sedimentation rates, the average is over $12 \mathrm{~m} / \mathrm{Ma}$, including compensation for the $2.2 \mathrm{Ma}$ long hiatus in the early late Miocene (Table 1). However, it is likely that the Neogene sedimentation rates in the central Arctic Ocean varied to some degree, but the currently available data cannot resolve these changes. The longest Neogene interval lacking any age/depth control point is in the approximately $48 \mathrm{~m}$ long interval separating the deepest ${ }^{10} \mathrm{Be}$ sample at $151 \mathrm{mcd}$ from the base of subunit $1 / 5$ at near $199 \mathrm{mcd}$. The use of lithological cyclostratigraphic data appears to be a promising, although still largely untested, way forward to improve the understanding, and thus the resolution, of Neogene sedimentation rates in the ACEX sequence. The recovered ACEX Paleogene sediments encompass a shorter time interval compared to the Neogene sediments, and shows a higher average sedimentation rate of nearly $18 \mathrm{~m} /$ Ma (Table 1). The major hurdle in the Paleogene age model is the age progression in subunit $1 / 6(198.7-223.56 \mathrm{mcd})$. Biostratigraphy based on biosiliceous indicators, and one of two alternative interpretations of the cyclostratigraphic data, suggests a much reduced, about $70 \%$, sedimentation rate compared to that of the underlying unit 2 (223.56-313.61 mcd). In this lithologic unit, the rate generated by the dinoflagellate biostratigraphy is wholly consistent with the

Figure 7. Chronologic distribution of ACEX lithologic units, including hiatuses, as they appear according to the age model of this study. Reflection seismic units LR-3 to LR-6 are from Jokat et al. [1995]. Core-seismic interpretation of this study permitted correlation of the Jokat et al. seismostratigraphic units to the ACEX lithostratigraphy. A combination of three different timescale segments are used (see text). 


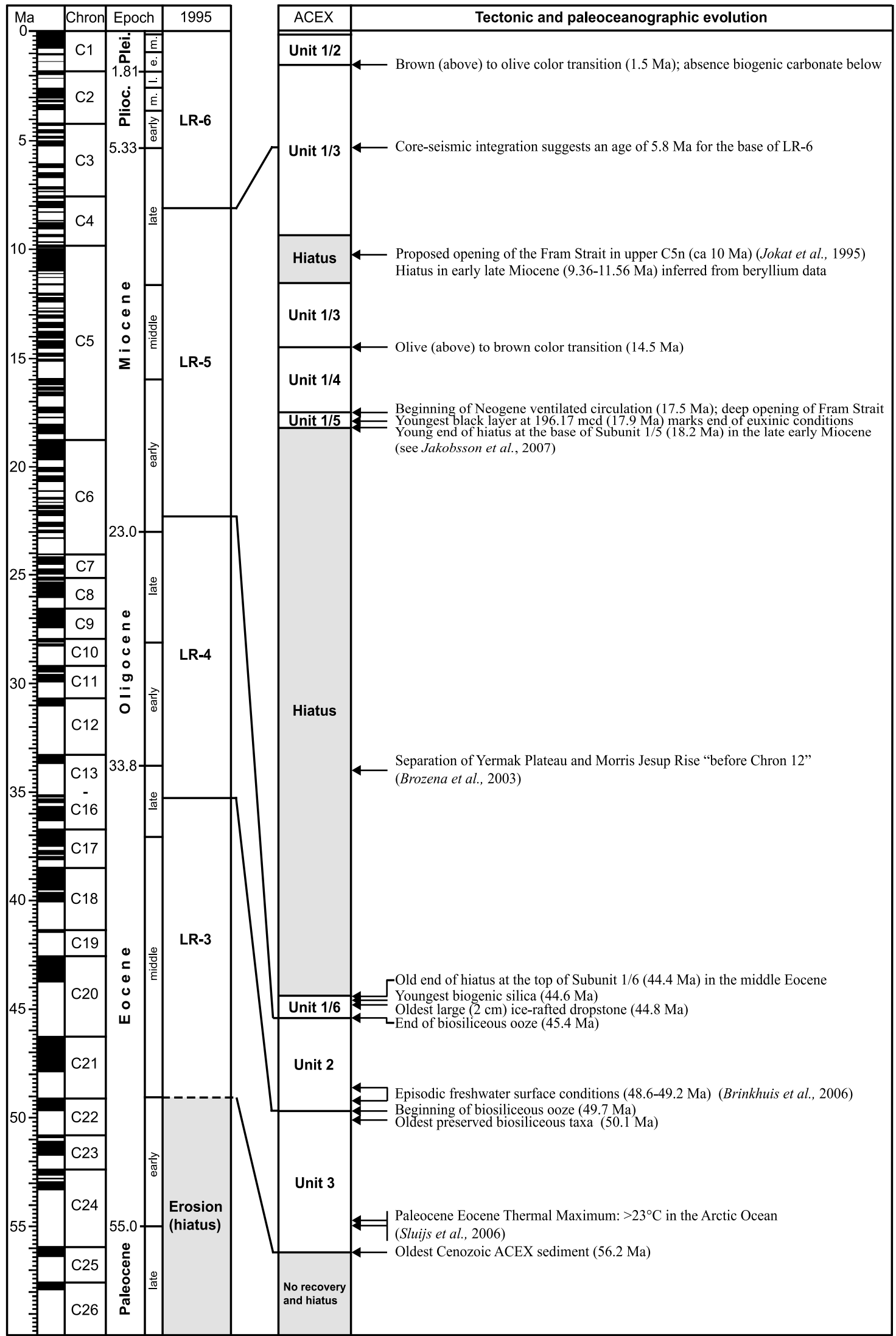

Figure 7 
cyclostratigraphic data. In the case of a sedimentation rate of $7 \mathrm{~m} / \mathrm{Ma}$, a value representing the second interpretation from the cyclostratigraphic data, is applied for subunit $1 / 6$, resulting in an age estimate of $41.9 \mathrm{Ma}$ for the $198.70 \mathrm{mcd}$ level and the old end of the hiatus. However, this possibility is still not compatible with the critical diatom event, the FO of $C$. aff. tenerrimus, at $203.12 \mathrm{mcd}$. Using a $7 \mathrm{~m} / \mathrm{Ma}$ rate within subunit $1 / 6$ results in an age estimate of $42.5 \mathrm{Ma}$ for the 203.12 mcd level, which is 5.8 million years older than the best available, calibrated age estimate of $C$. aff. tenerrimus of $36.7 \mathrm{Ma}$. Thus we chose to rely on the apparently unambiguous biostratigraphy provided by the dinoflagellate cysts for subunit $1 / 6$, which is consistent with one of the two alternative interpretations of the cyclostratigraphic data, generating a approximately $20 \mathrm{~m} / \mathrm{Ma}$ sedimentation rate within subunit $1 / 6$. A mere $29 \%$ of Cenozoic time is represented in the ACEX sediments (Figure 7), but the oldest $8.8 \mathrm{Ma}$ (14\% of Cenozoic time) of Paleocene time is not likely to be found or recovered from the Lomonosov Ridge because of its tectonic history [Jokat, 2005; Jokat et al., 1992, 1995]. Thus, despite the ACEX effort, huge data gaps still exist with respect to the availability of Cenozoic sediments, and hence the paleoceanographic evolution, of the central Arctic Ocean. Chronostratigraphic and seismostratigraphic relationships of the ACEX sediments are summarized in Figure 7. The seismostratigraphic interpretations of profile AWI-91090 [Jokat et al., 1995], on which the ACEX sites were located, are linked to the ACEX lithostratigraphy using core-seismic correlation relationships. This seismostratigraphy is applicable over wide geographic areas in the Arctic Ocean. It follows that the age model of the ACEX sediments also is applicable in these same areas. The chronostratigraphic and seismostratigraphic relationships presented in Figure 7 therefore will be important when seeking future suitable coring targets in the central Arctic Ocean that have the potential to recover the interval lost in the prolonged early Miocene through middle Eocene hiatus in the ACEX sediments.

[28] Acknowledgments. The ACEX sediments were acquired through joint efforts of the IODP, ECORD, and the Swedish Polar Research Secretariat. Reviews by Mitchell Lyle and an anonymous reviewer contributed to improving the manuscript. J.B. acknowledges financial support from Stockholm University and the Swedish Research Council. M.O., K.M., and J.K. acknowledge the National Science Foundation funded U.S. Science Support Program for the IODP. C.S. acknowledges VISTA Project 6248.

\section{References}

Aksu, A. E., and P. J. Mudie (1985), Magnetostratigraphy and palynology demonstrate at least 4 million years of Arctic sedimentation, Nature, 318, 280-283.

Backman, J., M. Jakobsson, R. Løvlie, L. Polyak, and L. A. Febo (2004), Is the central Arctic Ocean a sediment starved basin?, Quat. Sci. Rev., 23, 1435-1454.

Backman, J., K. Moran, D. B. McInroy, L. A. Mayer, and the Expedition 302 Scientists (2006), Artic Coring Expedition (ACEX), Proc. Integr. Ocean Drill. Program, 302, doi:10.2204/ iodp. proc.302.2006

Bleil, U. (1987), Quaternary high latitude magnetostratigraphy, Polar Res., 5, 325327.

Brinkhuis, H., et al. (2006), Episodic fresh surface waters in the Eocene Arctic Ocean, Nature, 441, 606-609.

Brozena, J. M., V. A. Childers, L. A. Lawver, L. M. Gahagan, R. Forsberg, J. I. Faleide, and O. Eldholm (2003), New aerogeophysical study of the Eurasia Basin and Lomonosov Ridge: Implications for basin development, Geology, 31, 825-828.

Bukry, D. (1984), Paleogene paleoceanography of the Arctic Ocean is constrained by the middle or late Eocene age of USGS Core FI-422: Evidence from silicoflagellates, Geology, 12, 199-201.

Cande, S. C., and D. V. Kent (1995), Revised calibration of the geomagnetic polarity timescale for the Late Cretaceous and Cenozoic, J. Geophys. Res., 100, 6093-6095.

Clark, D. L. (1970), Magnetic reversals and sedimentation rates in the Arctic Basin, Geol. Soc. Am. Bull., 81, 3129-3134.

Clark, D. L. (1974), Late Mesozoic and early Cenozoic sediment cores from the Arctic Ocean, Geology, 2, 41-44.
Clark, D. L., R. R. Whitman, K. A. Morgan, and S. D. Mackay (1980), Stratigraphy and glacial-marine sediments of the basin, central Arctic Ocean, Spec. Pap. Geol. Soc. Am., 181, 1-57.

Clark, D. L., B. J. Kowallis, L. G. Medaris, and A. L. Deino (2000), Orphan Arctic Ocean metasediment clast: Local derivation from Alpha Ridge pre-2.6 Ma ice rafting?, Geology, 28, $1143-1146$

Coe, R. S., and J. C. Liddicoat (1994), Overprinting of natural magnetic remanence in lake sediments by a subsequent high-intensity field, Nature, 367, 57-59.

Damassa, S. P. (1998), A hole-Y alliance: Calciodinelloidean archeopyles in dinosporin cysts, Palynology, 22, 238.

Eldrett, J. S., I. C. Harding, J. V. Firth, and A. P. Roberts (2004), Magnetostratigraphic calibration of Eocene-Oligocene dinoflagellate cyst biostratigraphy from the Norwegian-Greenland Sea, Mar. Geol., 204, 91-127.

Frank, M., J. Backman, M. Jakobsson, K. Moran, M. O’Regan, J. King, B. A. Haley, P. W. Kubik, and D. Garbe-Schönberg (2008), Beryllium isotopes in central Arctic Ocean sediments over the past 12.3 million years: Stratigraphic and paleoceanographic implications, Paleoceanography, 23, PA1S02, doi:10.1029/2007PA001478.

Gubbins, D. (1999), The distinction between geomagnetic excursions and reversals, Geophys. J. Int., 137, F1-F3.

Herman, Y. (1974), Arctic Ocean sediments, microfauna, and the climatic record in late Cenozoic time, in Marine Geology and Oceanography of the Arctic Seas, edited by Y. Herman, pp. 283-348, Springer, Berlin.

Jakobsson, M., N. Z. Cherkis, J. Woodward, B. Coakley, and R. Macnab (2000), A new grid of Arctic bathymetry: A significant resource for scientists and mapmakers, Eos Trans. $A G U$, 81(9), 89

Jakobsson, M., et al. (2007), The early Miocene onset of a ventilated circulation regime in the Arctic Ocean, Nature, 447, 986-990.

Jiang, N., D. Neelin, and M. Ghil (1995), Quasiquadrennial and quasi-biennial variability in the equatorial Pacific, Clim. Dyn., 12, $101-$ 112.

Jokat, W. (2005), The sedimentary structure of the Lomonosov Ridge between $88^{\circ} \mathrm{N}$ and $80^{\circ} \mathrm{N}$, Geophys. J. Int., 163, 698-726, doi:10.1111/j1365-246X2005.02786.X.

Jokat, W., G. Uenzelmann-Neben, Y. Kristoffersen, and T. Rasmussen (1992), ARCTIC'91: Lomonosov Ridge-A double sided continental margin, Geology, 20, 887-890.

Jokat, W., E. Weigelt, Y. Kristoffersen, T. Rasmussen, and T. Schöne (1995), New geophysical results from the south-western Eurasian Basin (Morris Jesup Rise, Gakkel Ridge, Yermak Plateau) and the Fram Strait, Geophys. J. Int., 123, $601-610$.

Jokat, W., R. Stein, E. Rachor, I. Schewe, and Shipboard Scientific Party (1999), Expedition gives fresh view of central Arctic geology, Eos Trans. $A G U, 80(40), 465$.

Langinen, A. E., D. G. Gee, N. N. LebedevaIvanova, and Y. Y. Zamansky (2003), Velocity structure and correlation of the sedimentary cover on the Lomonosov Ridge and in the Amerasian Basin, Arctic Ocean, in Proceedings of the Fourth International Conference on Arctic Margins, ICAM IV, edited by R. A. Scott and D. K. Thurston, pp. 179-188, U. S. Dep. of the Inter., Anchorage, Alaska.

Laskar, J. (1999), The limits of Earth orbital calculations for geological time-scale use, Philos Trans. R. Soc. London, Ser. A, 357, $1735-$ 1759. 
Laskar, J., P. Robutel, F. Joutel, M. Gastineau, A. C. M. Correia, and N. Levrard (2004), A long-term numerical solution for the insolation quantities of the Earth, Astron. Astrophys., 428, 261-285, doi:10.1051/0004-6361: 20041335.

Lourens, L. J., F. J. Hilgen, N. J. Shackleton, J. Laskar, and D. Wilson (2004), The Neogene period, in A Geological Time Scale 2004, edited by F. M. Gradstein et al., pp. 409440, Cambridge Univ. Press, Cambridge, U. K.

Løvlie, R., B. Markussen, H. P. Sejrup, and J. Thiede (1986), Magnetostratigraphy in three Arctic Ocean sediment cores: Arguments for magnetic excursions within oxygen-isotope stage 2-3, Phys. Earth Planet. Inter., 43, 173-184.

Manum, S. B., M. C. Boulter, H. Gunnarsdottir, K. Rangnes, and A. Scholze (1989), Eocene to Miocene palynology of the Norwegian Sea (ODP Leg 104), in, Proc. Ocean Drill. Program Sci. Results, 194, 611-662.

Mayer, L. A., T. H. Shipley, F. Theyer, R. H. Wilkens, and E. L. Winterer (1985), Seismic modeling and paleoceanography at Deep Sea Drilling Project Site 574, Initial Rep. Deep Sea Drill. Proj., 85, 947-970.

Moran, K., et al. (2006), The Cenozoic palaeoenvironment of the Arctic Ocean, Nature, 441, $601-605$.

Nowaczyk, N. R., T. W. Frederichs, A. Eisenhauer, and G. Gard (1994), Magnetostratigraphic data from late Quaternary sediments from the Yermak Plateau, Arctic Ocean: Evidence for four geomagnetic polarity events within the last $170 \mathrm{ka}$ of the Brunhes Chron, Geophys. J. Int., 117, 453471

Nowaczyk, N. R., T. W. Frederichs, H. Kassens, N. Nørgaard-Pedersen, and R. F. Spielhagen (2001), Sedimentation rates in the Makarov Basin, central Arctic Ocean: A paleomagnetic and rock magnetic approach, Paleoceanography, 16, 368-389.

Nowaczyk, N. R., M. Antonow, J. Knies, and R. F. Spielhagen (2003), Further rock magnetic and chronostratigraphic results on reversal excursions during the last $50 \mathrm{ka}$ as derived from northern high latitudes and discrepancies in precise AMS ${ }^{14} \mathrm{C}$ dating, Geophys. J. Int., $155,1065-1080$.

O'Regan, M., J. W. King, J. Backman, M. Jakobsson, K. Moran, C. Heil, T. Sakamoto, T. Cronin, and R. Jordan (2008a), Constraints on the Pleistocene chronology of sediments from the Lomonosov Ridge, Paleoceanography, doi:10.1029/2007PA001551, in press.

O'Regan, M., et al. (2008b), Mid-Cenozoic tectonic and paleoenvironmental setting of the central Artic Ocean, Paleoceanography, doi:10.1029/2007PA001559, in press.
Pagani, M., N. Pedentchouk, M. Huber, A. Sluijs, S. Schouten, H. Brinkhuis, J. S. Sinninghe Damsté, G. R. Dickens, and Expedition-Scientists (2006), Arctic hydrology during global warming at the Palaeocene-Eocene thermal maximum, Nature, 442, $671-675$.

Pälike, H., R. D. Norris, J. O. Herrle, P. A. Wilson, H. K. Coxall, C. H. Lear, N. J. Shackleton, A. K Tripati, and B. S. Wade (2006a), The heartbeat of the Oligocene climate system, Science, 314, 1894-1898.

Pälike, H., J. Frazier, and J. C. Zachos (2006b), Extended orbitally forced palaeoclimatic records from the equatorial Atlantic Ceara Rise, Quat. Sci. Rev., 25, 3138-3149, doi:10.1016/ j.quascirev.2006.02.011.

Pälike, H., D. J. A. Spofforth, M. O'Regan, and J. Gattacecca (2008), Orbital scale variations and timescales from the Arctic Ocean, $P a$ leoceanography, doi:10.1029/2007PA001490, in press.

Plaut, G., and R. Vautard (1994), Spells of lowfrequency oscillations and weather regimes in the Northern Hemisphere, J. Atmos. Sci., 51, $210-236$.

Sangiorgi, F., H. Brinkhuis, and S. P. Damassa (2008a), Frigusphaera gen. nov.: A new organic-walled dinoflagellate cyst genus from the ?early Miocene of the central Arctic Ocean, Micropaleontology, in press.

Sangiorgi, F., E. E. van Soelen, D. J. A Spofforth, H. Pälike, C. E. Stickley, K. St. John, N. Koç, S. Schouten, J. S. Sinninghe Damste, and H. Brinkhuis (2008b), Cyclicity in the middle Eocene central Arctic Ocean sediment record: Orbital forcing and environmental response, Paleoceanography, doi:10.1029/ 2007PA001487, in press.

Scherer, R., and N. Koc (1996), Late Paleogene diatom biostratigraphy and paleoenvironments of the northern Norwegian-Greenland Sea, Proc. Ocean Drill. Program Sci. Results, 151, 75-99.

Shackleton, N. J., M. A. Hall, I. Raffi, L. Tauxe, and J. C. Zachos (2000), Astronomical calibration age from the Oligocene-Miocene boundary, Geology, 28, 447-450.

Sluijs, A., et al. (2006), Subtropical Arctic Ocean temperatures during the Palaeocene/Eocene thermal maximum, Nature, 441, 610-613.

Spiegler, D. (1996), Plankton foraminifer biostratigraphy of the Arctic Ocean, Fram Strait (Sites 908-909), Yermak Plateau (Sites 910-912), and East Greenland Margin (Site 913), Proc. Ocean Drill. Program Sci. Results, $151,153-167$

Spielhagen, R. F., et al. (1997), Arctic Ocean evidence for late Quaternary initiation of northern Eurasian ice sheets, Geology, 25, $783-786$.

Spofforth, D. J. A., H. Pälike, and D. Green (2008), Paleogene record of elemental concen- trations in sediments from the Arctic Ocean obtained by XRF analyses, Paleoceanography, doi:10.1029/2007PA001489, in press.

Stein, R., B. Boucsein, and H. Meyer (2006), Anoxia and high primary production in the Paleogene central Arctic Ocean: First detailed records from Lomonosov Ridge, Geophys. Res. Lett., 33, L18606, doi:10.1029/ $2006 \mathrm{GL} 026776$.

Steuerwald, B. A., D. L. Clark, and J. A. Andrew (1968), Magnetic stratigraphy and faunal patterns in Arctic Ocean sediments, Earth Planet. Sci. Lett., 5, 79-85.

Stickley, C. E., N. Koç, H.-J. Brumsack, R. W. Jordan, and I. Suto (2008), A siliceous microfossil view of middle Eocene Arctic paleoenvironments: A window of biosilica production and preservation, Paleoceanography, doi:10.1029/2007PA001485, in press.

Thiede, J., D. L. Clark, and Y. Herman (1990), Late Mesozoic and Cenozoic paleoceanography of the northern polar oceans, in The Geol ogy of North America, vol. L, The Arctic Ocean Region, edited by A. Grantz et al., pp. 427-458, Geol. Soc. of Am., Boulder, Colo.

Torrence, C., and G. P. Compo (1998), A practical guide to wavelet analysis, Bull. Am. Me teorol. Soc., 79, 61-78.

Williams, G. L., and S. B. Manum (1999), Oligocene-early Miocene dinocyst stratigraphy of Hole 985A (Norwegian Sea), Proc. Ocean Drill. Program Sci. Res., 162, 99-109.

J. Backman and M. Jakobsson, Department of Geology and Geochemistry, Stockholm University, S-10691, Stockholm, Sweden. (backman@ geo.su.se)

H. Brinkhuis and F. Sangiorgi, Laboratory of Palaeobotany and Palynology, Utrecht University, NL-3584 CD, Utrecht, Netherlands.

M. Frank, Leibniz Institute for Marine Sciences at University of Kiel (IFM-GEOMAR), D-24148 Kiel, Germany.

J. Gattacecca, Department of Geophysics and Planetology, CEREGE, CNRS, University of Aix-Marseille, F-13545 Aix-en-Provence, France.

C. Heil, J. King, K. Moran, and M. O’Regan, Graduate School of Oceanography and Department of Ocean Engineering, University of Rhode Island, Narragansett, RI 02881, USA.

R. Løvlie, Department of Earth Science, University of Bergen, N-5007 Bergen, Norway.

H. Pälike and D. Spofforth,School of Ocean and Earth Science, National Oceanography Centre, University of Southampton, Southampton SO14 3ZH, UK.

C. Stickley, Norwegian Polar Institute, N-9296 Tromsø, Norway. 